\title{
THE ROLE OF GENERIC COMPETENCE AND PROFESSIONAL EXPERTISE IN LEGAL TRANSLATION. THE CASE OF ENGLISH AND POLISH PROBATE DOCUMENTS
}

\begin{abstract}
This paper seeks to demonstrate how the concept of generic competence (primarily intended for monolingual specialized communication) could be extended to address important issues in translating legal texts. First, generic competence is discussed against the backdrop of the related concept of translation competence. Then, a case study is presented which examines a closely related set of documents employed by the professional community of lawyers (represented by an English solicitor and Polish advocate) engaged in the specialist domain of probate law (legal process related to the estate of a deceased person). It is argued that both generic competence and professional expertise should be included in the range of competencies required for the translator of legal texts.
\end{abstract}

Keywords: genre, generic competence, professional expertise, legal translation, professional practice

This paper attempts to contribute to the discussion on the nature and types of skills needed for translating specialized texts. It aims to demonstrate the relevance and applicability of the concept of generic competence to the process of translating legal documents. Generic competence and the related concept of professional expertise have been seldom explored in the context of skills required by legal translators. Yet, it seems that generic competence does not only carry important implications for different types of recontextualization (cf. simplification and easification of professional texts proposed in Bhatia 2004) but there are some good reasons to regard it as crucial to the success of interlingual translational activities done in professional legal contexts. One of the most common problems in specialized translation is that translators usually do not belong to a particular pro- 
fessional community or 'community of practice' (Lave and Wenger 1991). This issue seems to be particularly relevant in the case of the legal profession which requires a long period of both formal university education and professional practice before an aspiring law student is admitted to the profession. As a result, the legal profession is not easily open to the uninitiated. Legal translators without a formal legal training are bound to be outsiders with a limited access to the inner workings of legal institutional practice.

Another common problem is of more pedagogic nature and it concerns the frequent use of single isolated texts in the classroom practice, which are often detached from the larger extralinguistic realities of the world of law. In consequence, legal translators may face serious deficiencies in their professional expertise (Bhatia 2004). In this article, I argue for an approach to translating legal texts which relies on the concept of generic competence. I intend to demonstrate that this genre-based view of legal translation as part of the professional practice can greatly facilitate the translation process and help to remedy some of the deficiencies in professional expertise encountered by translators. In order to prepare the ground for further discussion, I first turn to give a brief overview of the concepts of translation competence and generic competence in the hope of shedding some light on the nature of their relations. Then I move on to present a case study in translating a genre set of closely documents employed by the professional community of lawyers (represented by an English solicitor and Polish advocate) engaged in the specialist domain of probate law. The texts selected for the analysis come from the author's own translation practice and they were obtained in the course of a few years' experience of cooperating with a Polish lawyer.

\section{An Overview of Translation Competence, Translator Competence and Generic Competence}

The question of what skills translators need to perform their job satisfactorily has been usually studied within the context of the concept of translation competence (see Pietrzak 2015 for an up-to-date overview). Translation competence belongs to those elusive concepts that have attracted a great deal of attention resulting in a plethora of different definitions and perspectives. Generally, there are two main approaches to defining translation competence: the minimalist approach, also referred to as the concept of supercompetence, and the multicomponent idea of competence ${ }^{1}$. The for- 
mer assumes that it is simply not feasible (and perhaps there is no real need) to define the totality of knowledge and to list all the skills that the translator should possess in order to translate competently. In his well-known minimalist definition, Pym (2003: 489) points to two basic abilities: one involves generating different versions of the target text and the other is concerned with selecting "only one viable TT from this series, quickly and with justified confidence". On the other hand, the multicomponent idea of competence consists in listing various, sometimes very detailed skills considered as necessary ingredients of translation competence. For example, Hansen (2008: 274) perceives translation competence in terms of a combination of skills derived from four major components: knowledge terminology, translation theories, language cultures and translation technology. However, this view of competence often results in identifying some very vague skills or subskills, such as attentiveness, courage or the ability to work under pressure (Pietrzak 2015: 322). It seems that both approaches are not without some limitation. The first may strike one as too general to be of immediate pedagogic value, especially in the context of specialized communication. The second is also problematic because a detailed enumeration of all possible competences (or subcompetences) seems impracticable given the diversity of translators' tasks, their specializations and recent developments on the translation market, such as professionalization, globalization and specialization (Biel 2011: 164).

The question of translation competence is further complicated by the related concept of translator competence. In essence, translation competence is regarded as the ability to provide a good quality target text that meets the required standard, while translator competence covers skills required to function as a professional on the market. It is not quite clear why these two aspects of translator work should be held separate. It seems that in the context of professional communication, it is not possible to create a text that would conform to the expectations and conventions of a professional community without acquiring professional expertise and interacting with members of such community. Thus, these two concepts seem to be closely intertwined.

The concept of generic competence was proposed by Vijay K. Bhatia within the larger framework of his four-space model of discourse. ${ }^{2}$ In fact, generic competence is one of three competences underlying the more general discursive competence. The other two include social competence and textual competence. Generic competence can be best defined as the ability to exploit successfully a range of genres to achieve the goals of a specific professional community. 
This means that LSP users who possess generic competence are aware of a repertoire of text genres typically employed in the course of a given professional practice and they know how to use them in order for the whole process to go in a smooth and timely manner.

In addition, translators should be able to recognize generic integrity of the texts they deal with. One of the most important aspects of generic constructs is that they should be readily recognizable by members of a specific professional community and that they have been adequately standardized. This property of genre carries enormous implications for translation because it defines the standard required of target texts intended for professional communication. It determines whether the translator has succeeded in constructing a professional text genre. This can be only achieved if the genre has recognizable generic integrity. Introduced originally in Bhatia (1993) and subsequently discussed in his numerous publications, this concept has been primarily intended for LSP communication. It has been seldom invoked explicitly in translation. Generic integrity is defined in Bhatia (2004: 123) as "a socially constructed typical constellation of form-function correlations representing a specific professional, academic or institutional communicative construct realizing a specific communicative purpose of the genre in question". Thus, the successful recontextualization of a professional text in a target language consists in retaining both its textual and its conventionalized, typified generic meaning.

However, what is less obvious, but also much needed, is the ability to "exploit generic knowledge to create new forms to express 'private intentions' within the socially recognized goals" (Bhatia 2004: 145). Even though genres are rightly perceived as highly conventionalized, recognizable and standardized linguistic artefacts (Swales 1990), experienced professionals may sometimes decide to deviate from the generic conventions to create a form that suits their professional (or personal) goals. Again, translators should be aware of such practices and they should know how to react whenever there is a conflict between the goal of a professional commissioning the translation and the institutional goal (this point will be raised later in this article when the case study is discussed).

In sum, generic competence does not only call for an active participation in the discursive procedures resulting in the creation of actual generic constructs, i.e. texts, but also in the active participation in the professional practices. There is no space in this paper to explore at length the relations between translation competence and generic competence. Clearly, the concept of generic competence was not proposed only for translators but rather for the wide and heterogeneous group of LSP users. But in many 
respects there is a wide area of overlap between the two concepts. In addition, generic competence appears to be more specific and better suited to the requirements and needs of legal translation.

\section{The Law of Succession and the Concept of Probate. A Comparative Note on Terminology}

In common-law countries the law of succession is the branch of law which regulates how and which beneficiaries become entitled to property under a will or on intestacy (when no will has been made). A gift by will of real estate is known as devise and the beneficiary is called the devisee. There are three types of devise. It may be specific (e.g. "my house to A"), general (e.g. All my real property to B") or residuary ("the rest of my real property to C"). On the other hand, legacy is a gift of personal property (and there are also different types of legacy) under a will, and legatee is a beneficiary of a legacy. In the case of intestacy, any property that a beneficiary receives is known as inheritance (Martin \& Law 2006).

This conceptualization of the devolution of property on the death of its owner raises important terminological issues with regard to the translation of the relevant terminology. Polish legal terminology does not distinguish between property left under a will or on intestacy. In both cases, the equivalent term is spadek and the beneficiary is called spadkobierca. In consequence, the Polish term spadek may correspond to three English terms: inheritance, devise, legacy or bequest (cf. Berezowski 2015: 98). It should be noted that it is possible to distinguish between the beneficiary under a will and on intestacy by means of spadkobierca testamentowy and spadkobierca ustawowy, respectively. Where a specific legacy or devise is made, the beneficiary is called zapisobierca in Polish legal terminology. Just as in the case of spadek, the Polish term zapisobierca is used regardless of whether the property concerns realty or personalty.

The term probate (which in Polish corresponds to the term badanie ważności testamentu) denotes the legal process that has to be followed after somebody's death (Martin \& Law 2006). If the deceased person left a will, then the person(s) responsible for the administration of the estate will be the executor (wykonawca testamentu in Polish) named in the will. They will be responsible for collecting the deceased person's assets, distributing the estate and paying any debts. The aim of probate is to gain legal acceptance that a will is valid. Before assets can be collected and the estate administered, the executors have to apply to the probate registry for 
what is known as a grant of probate (Pol. poświadczenie autentyczności testamentu). The grant is a legal document which can be presented to various financial institutions to collect the deceased's assets such as money, shares or property. ${ }^{3}$

\section{A Case Study in Translating a Genre Set of Probate Documents}

In what follows I turn to analyze a genre set used in legal proceedings related to probate. The term genre set is used after Devitt (1991) to refer to a range of written genres employed in the professional practice. For example, Devitt discusses several distinct but intertextually linked letters, such as an opinion letter to the client, a response letter to the client, a letter to tax authorities, etc. In a similar vein, Candlin \& Bhatia (1998) demonstrate how this concept could be used in the case of a solicitor's professional activity. The professional interaction between a solicitor and her client usually involves performing a set of tasks, such as preparing a client file, a legal brief, a letter of advice, etc. A genre set is thus a grouping of distinct, yet related generic constructs which are employed within the same, usually precisely defined professional activity with a clearly designated agent (a professional). ${ }^{4}$ This concept is important for legal translation because it shows that documents usually appear in the context of other documents in a specific sequence. In the present case, the genre set includes two letters written by an English solicitor representing the case before the Probate Court in England, a precedent of an affidavit, court notes and an affidavit drafted by a Polish advocate in Polish and then translated into English.

The present case concerns a Polish testator residing in the UK who died leaving a will written in Polish and made under Polish law. The beneficiaries include Polish and English individuals as well as certain institutions. There are two executors of the estate. One is a Polish advocate ${ }^{5}$ and the other is English. Property to be distributed among several beneficiaries includes money kept in an English bank and legally designated as 'legacies'. It should be pointed out at this stage that the Polish advocate was an elderly person with over 40 years of experience before Polish courts but no knowledge of English and having little experience of dealing with legal matters in international contexts. As a result, all the documents in English were translated into Polish and then the Polish affidavit had to be back-translated into English. Finally, another letter from the English solicitor providing a response and a sort of feedback to the translated affidavit was rendered into Polish. In 
sum, the translation practice embedded within the larger framework of legal proceedings and described in this paper consists of three stages: (1) translating a letter from a solicitor, court notes and a precedent of an affidavit from English into Polish; (2) translating the affidavit from Polish into English and (3) translating a letter from a solicitor from English into Polish.

\section{The Affidavit}

Central to the documents exchanged in the legal proceedings is a document called an affidavit. It is a sworn written statement used as evidence in court proceedings. The person who makes the affidavit must swear of affirm that the contents are true before a person authorized to take oaths in the particular kind of affidavit. ${ }^{6}$ This means that there is no universal form of such document commonly used under the common law system. Rather, a particular institution, i.e. a court of law, may provide a specific form, a model to be followed by other interactants (see Table 1). In order for the document to be valid, an affidavit must be notarized. This is usually done by notaries public. In Polish, the corresponding term is oświadczenie złożone pod przysiega (cf. Berezowski 2015: 178) and there is no generally prescribed form for making such statements. The first section of the document serves the purpose of stating the credentials of the person making the affidavit, technically known as the deponent. It contains the key phrase make oath and say, which is a legal performative, i.e. it performs the act of solemnly declaring that the information provided below is true to the best of this person's knowledge. This phrase also appears in a reduced form as in I say. It is thus a key performative verb in the affidavit. Other key terms or expressions include, for example last will and testament, laws and constitution, the question of validity, custody, beneficially entitled to the estate. The text is marked stylistically as it contains certain archaic expressions such as aforementioned, said, and verily. It is a fine example of legalese.

Table 1

The precedent of an affidavit

IN THE HIGH COURT OF JUSTICE

FAMILY DIVISION

The District Probate Registry at Bristol

IN THE ESTATE OF .... DECEASED

$\mathrm{I}, \mathrm{CD}$, of [an advocate or other person conversant with the laws of the country], make oath and say that: 
1. I am conversant with the laws and constitution of $\mathrm{X}$ and practice [or have practised for ...years] as an advocate in the courts of that country [or, if the deponent is other than an advocate, his full qualifications should be stated].

2. I have referred to the [official (or notarial) copy of the] last will and testament of $A B$ of deceased, bearing the date the day of 20 and now produced to me and marked 'A'; and I say that the said will was made in conformity with the internal law of X and is valid by the aforesaid laws and constitution [or is accepted as valid under the said laws and constitution of $\mathrm{X}$ if it is valid under the internal law of $\mathrm{Y}$, to which the question of validity is referred by the law of $\mathrm{X}$ because...]. [Add where necessary: Under the aforesaid laws and constitution the original of the said will is deposited permanently at the (Wills Registry at ......) (office of MN, notary at ...) and cannot be removed from such custody. The aforesaid copy of the said will is acceptable in the courts of $\mathrm{X}$ as evidence of the contents of the original will.]

3. [I am informed and verily believe (set out facts leading to deponent's conclusions see Note 2 to this form).

4. In the aforesaid circumstances I say that EF and GH are according to the aforesaid laws and constitution the persons beneficially entitled to the estate of the said deceased.]

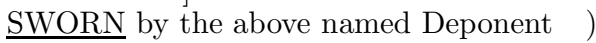

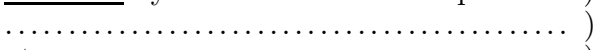

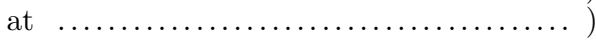

this day of $\quad 2010 \quad$ )

Before me,

A Notary Public

[See notes overleaf $]$

This precedent contains an explicit reference to Notes, which is the second document attached to the letter and which offers further guidance as to the way in which the affidavit should be drafted and what it should contain (see Table 2). As in the text of the precedent, validity is also the key term in the Notes. In addition, attention should be paid to the concept of execution of will, which refers to the process by which testator's will is made legally valid. Needless to say, both the precedent and the Notes represent texts that are decontextualized. They have not been prepared for any specific case. Rather, the documents have been designed to be comprehensive and all-inclusive. It is then up to the LSP user to select content that is relevant to their needs. For example, in the Notes it says that an affidavit should show whether there is a single system of law relating to the formal validity of wills or whether there is more than one such system. The option of more than one legal system could apply in states with a federal legal system as in the United States or Germany. In this case, the affidavit should clearly state that a single system of law applies in Poland in respect of the probate. The Notes, made available by the Probate Registry in Bristol, can be regarded as an instance of 'meta-genre', i.e. genre whose function is "to provide shared background knowledge and guidance in how to produce and negotiate gen- 
res within systems and sets of genres" (Giltrow (2001: 190). In the present case, the meta-genre has taken the form of guidelines or a manual to clarify points of relevant law and to advise the deponent on how to produce the document in question.

Table 2

Court Notes made available by the Probate Registry in Bristol

Notes

(1) When it is sought to establish the validity of execution of a will under the Wills Act 1963, the affidavit of law should deal with the internal law of the territory or state concerned excluding any question of reference to the law of any other country. In order to comply with s 6(2) of the Act, the affidavit should show whether a single system of law relating to the formal validity of wills obtains throughout the territory or state, or whether there is more than one such system. If the latter is the case, the affidavit should also show whether there is in force throughout the territory or state a rule indicating which system is to be applied to the case in question: if so, the deponent's opinion as to the validity of the execution of the will etc. should be based on the application of that rule. If there is no such rule, the deponent should state upon which system his conclusions are based. In this latter case, it will also be necessary to show in the affidavit of facts upon what grounds it is claimed that the deceased was most closely connected, at the time of execution of the will or at the time of his death (whichever is the relevant time: see s 6(2)(b) of the Act), with the system of law referred to in the affidavit of law.

(2) On an application for a grant under NCPR 30, the affidavit of law should refer to the facts and state the law applicable, but this must be supported by adequate evidence (normally on affidavit, or statement in the oath) as to the facts themselves (Registrar's Direction (1992) 20 November).

The interlingual transfer in this case calls for making the Polish counterparts as informative as possible since the two texts provide the basis for the Polish advocate to draft an affidavit relevant to this specific case. Thus, the translation should indicate the points that the affidavit must contain and its overall function.

\section{The Letter}

Both the affidavit and the Notes appeared as attachments to a letter written by an English solicitor who is probating the deceased's estate before the English court. The letter is addressed to the English co-executor of the estate but it was later forwarded to the Polish lawyer. This letter is crucial to the communication between the English and Polish lawyers as it provides clarification of the on-going proceedings before the English court and it specifies the task and role expected from the Polish advocate. 


\section{Table 3}

\section{A letter written by the English solicitor with the text anonymised}

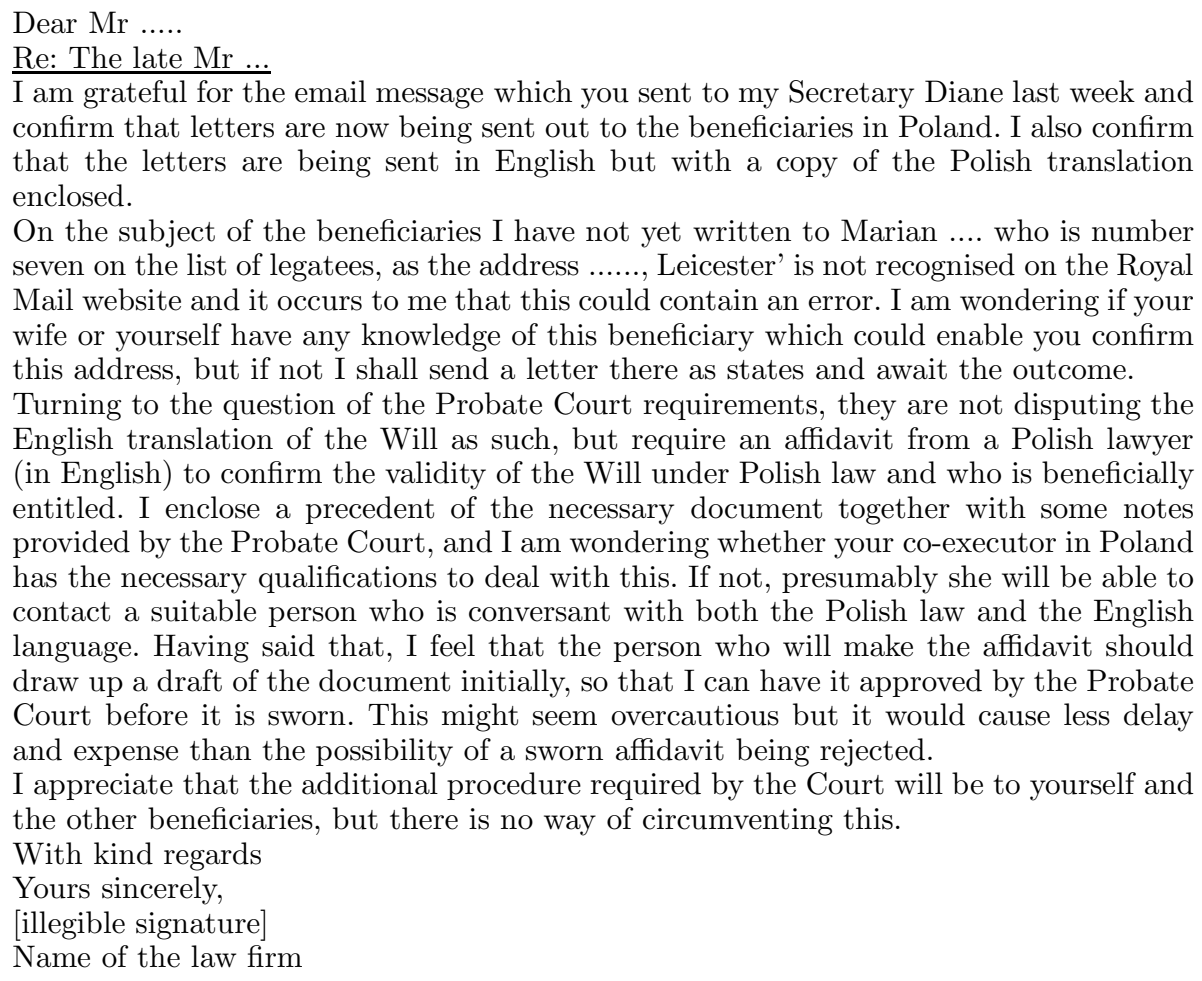

The letter specifies that the Polish advocate is expected to draft in English an affidavit, which will be then sent to the English Probate Court. This affidavit must contain two important points. First, it must confirm that the will is valid under Polish law and then it should clearly specify the legatees, i.e. name the persons who are eligible to benefit from the will. This document is necessary to obtain Grant of Probate, a document which will enable the co-executors to distribute the property left in the will. It is essential that the affidavit follows a specific and prescribed format. The importance of complying with this requirement is stressed by the request made in the letter that the draft should be first sent to the English solicitor for initial approval and also by attaching the precedent of an affidavit. The letter also mentions explicitly "the possibility of a sworn affidavit being rejected". Put differently, this letter communicates the need for maintaining generic integrity in the affidavit that is going to be prepared by the Polish lawyer and it warns of possible consequences if a member of the judicial community 
does not recognize it as a valid representative of its genre. The letter also specifies the competencies needed to complete this part of the professional practice successfully. The person preparing the affidavit should know both the Polish law and the English language. Since the Polish lawyer did not possess the latter, she had to commission the translation.

\section{The Affidavit Translated into English}

The three documents provided above after being translated provided an input on the basis of which the advocate prepared an affidavit in Polish. Table 4 provides the text of the affidavit translated into English. As it turned out, the Polish advocate did not follow closely the prescribed form of the document. Rather, she chose to include in her draft certain additional content. The text of the affidavit has been marked to indicate areas of overlap and divergence between the precedent and this version. The italicized parts indicate parts of the text that were created in accordance with the model and the underlines parts represent 'legitimate' additions prompted by suggestions from the Notes and/or the precedent. The italicized parts have their direct and functional counterparts in the source texts, i.e. the precedent and the court notes. However, the excerpts marked in bold show content that can be considered redundant in light of the overall function of this document in the probate proceedings and the specific provisions of the precedent. It should be noted that only Section 3 of the original text (the precedent) invites the deponent to provide additional information as shown in the following excerpt: set out facts leading to deponent's conclusions. In the other sections, the type of information needed is defined quite accurately. On examining the text in Table 4, it becomes immediately clear that a substantial part of the Target Version consists of some extra content raising questions if such additions are justified and acceptable. To a large extent, the translator relied on the phraseology of the Precedent. This is particularly conspicuous in the first part of the document sentences (1)-(3) fairly closely corresponds to what can be found in Sections 1 and 2 of the Precedent. In sentence (2) of the Target Version, the will is specified as 'holographic' and the sentence provides certain details concerning the court's address. This type of expansion of the original form is understandable and perhaps even necessary.

Note, however, sentences (4) and (5), which provide information that seems to be redundant and extraneous from the perspective of the addressee. For example, the fact that the copies of the will were sent to the English 
Table 4

The affidavit drafted in Polish and then back-translated into English.

Sentences have been numbered for ease of reference

(1) I, XYZ, make oath and say that:

I am conversant with the laws and constitution of Poland and have practised for 41 years as an advocate in the courts of that country.

(2) I have referred to the last will and testament of ...., which is a holographic will and the original of the said will is deposited permanently at the Eódź District Court (Sad Rejonowy) II Civil Division at Kościuszki 107/109 and cannot be removed from such custody. (3) The copies of the said will were issued by the same Court and verified as evidence of the contents of the original will. (4) They were already sent to Mr ...'s address in England. (5) In that case, the copies of the said will dated 24th of February 2009 and corrected on the 12th of September 2009 and then verified by the Court cannot be challenged by anyone or by any other court.

(6) Moreover, pursuant to Art. 949 \& 1 of the Polish Civil Code of 23rd of April 1964 (with further amendments), this said will as the last will of the deceased is valid because the aforementioned provision of the Polish Civil Code stipulates that "the testator may make his last will by writing it in full with his own hand, writing date on it and signing it".

(7) There is a single system of law relating to all matters in the territory of Poland. (8) In particular, the formal validity of wills is regulated by the Polish Civil Code. (9) Article $968 \S 1$ of the Civil Code provides for a testamentary disposition whereby a gift of personal or real property can be effected for the benefit of persons other than the inheritors. (10) Such persons to whom such gifts have been made are called zapisobiercy (legatees or devisees) by the Polish Civil Code. (11) In the present case, we deal with zapisobiercy (legatees). Pursuant to Art. 970 of the Polish Civil Code, zapisobiercy (legatees) are entitled "to demand their legacies as soon as the last will is declared open and read".

(12) In the aforesaid circumstances I say that the persons to whom bank legacies were made and who are mentioned in the said will as beneficially entitled (legatees) to the said estate of the said deceased in the following order 1, 2, 3, 4, 5, 6, 7, 8, 9, 10, 11, 12, 13, 14, 15 and 16 are entitled to demand from the executors of this will that the legacies be executed as soon as possible subject to Art. $986 \S 1$ of the Polish Civil Code and subject to Art. $988 \S 1$ of the Polish Civil Code.

co-executor does not appear to be relevant for the Court and the reason why the affidavit is required. In sentence (6) the deponent specifies the legal grounds for the validity of the will under Polish law, which is a legitimate expansion of the original form. Still, we find the information repeated in sentence (8), where another reference is made to the Polish Civil Code as the legal basis for determining the validity of wills in Poland. Sentences 9 through 11 go well beyond the scope of what is expected in this type of document. Here, the Polish lawyer drafting the text indulged in a lengthy explanation of a Polish legal term. In terms of the institutional goals of the Probate Registry, an affidavit is not an appropriate document in which to include such detailed explanations, even if the term zapisobiercy is not 
entirely unrelated to this case. The same comment as above applies to the statement contained in Sentence (5), which states that the copies of the will cannot be challenged by any individual or court. Such statement could be interpreted as a pre-emptive strategy to prevent the English Court from disputing the validity of the will. The discrepancy between the translation and the prescribed Precedent could also result from the Polish lawyer's attempt to achieve her own professional goal, i.e. defending the validity of the will and to speed up the probate process to serve the needs of the beneficiaries. What the Registry expected was a succinct and formulaic confirmation made by a qualified lawyer that the will is valid and that a specific group of individuals are entitled to benefit under it.

The affidavit drafted by the Polish advocate and subsequently translated into English turns out to be problematic from the perspective of the generic conventions of English affidavits. It includes content that appears to be redundant and/or extraneous to the immediate context of the legal proceedings before the English Court.

\section{The Second Letter From an English Solicitor Providing Negative Feedback}

The last document to be considered is another letter written by the English solicitor. The letter was sent in response to the translated affidavit and this time it is addressed directly to the Polish advocate. It provides further clarification of the context of the legal proceedings in which the affidavit was used. It emphasizes that, the executors of the estate can pay the legacies only if the court has issued the Grant of Probate. The Grant of Probate can only be issued if the affidavit proves the validity of the will and specifies the beneficiaries. This is also a response to the Polish advocate's claim for the immediate payment of the legacies under the will. This letter can also be regarded as much needed 'feedback' on the translated version of the affidavit. It communicates the rejection of the affidavit which is evidenced by the solicitor's request for another affidavit but this time one that would follow the prescribed form.

In other words, this letter attributes the problems with the translated affidavit the failure to preserve the generic integrity of the Precedent. The Court expects to receive a document which accurately and faithfully retains the textual form typical of English affidavits. This requirement is very clearly communicated in the letter by the insistent repetitions of "exact wording", "copy of the wording" and "using these exact words". 
Table 5

The second letter sent by the English solicitor in response to the translated Affidavit
AIR MAIL
Dear Madam,
Re: The late $\mathrm{Mr} \ldots$...

We thank you for your letter of the $17^{\text {th }}$ September and note what you say. We appreciate that there are bound to be delays in having letters translated.

The position in England is that the executors of an estate cannot withdraw any money from a bank account owned by the deceased person until the court has issued Grant of Probate. This is the reason why we have not yet been able to pay any fees or expenses, or to consider the question of dealing with the beneficiaries.

The English Probate Court is very strict in its requirements and we need a letter from you with the exact wording which we provided in November 2010. We enclose a copy of the wording and we need you to write a letter on your headed notepaper addressed to the Probate Court as shown, and using these exact words. We do not believe that any other letter or court document will be acceptable.

If you can let us have the letter as requested we hope to be able to obtain a Grant of Probate and then we would have access to the money in $\mathrm{Mr}$.... Bank accouns.

Yours faithfully,

[illegible signature]

[Name of the Solicitors' Firm]

Key words or phrases (in bold) were emphasized by the author of this paper

\section{Conclusion}

In this article, I attempted to demonstrate the need for including generic competence in the range of competencies required for the translator of legal texts. One possible way to overcome the problem deficiency in professional expertise is to engage translators with a degree in the legal system of the target language. Łachacz, R. Mańko (2013 argue that such a system implemented in the Translation Service of the Court of Justice of the EU proves to be immensely efficient in guaranteeing high-quality translations of legal texts that are properly understood by their audiences in the target language. Yet, it does not seem to be realistic to impose such requirements with regard to translation jobs commissioned by individuals or small legal firms. At the same time, the case study discussed above suggests that perhaps generic competence and professional expertise should be also acquired by law professionals working in international contexts.

As Bhatia points out the relationship between generic competence and professional expertise is not entirely clear (2004: 142-143) but there is no doubt that one enriches the other. Yet, the issue of how generic competence and professional expertise are acquired remains unaccounted for. The same 
applies to the acquisition of professional genres. This paper suggests that analyzing a genre set which was employed at different stages in an actual professional practice could be one of the sources for acquiring generic competence. A range of texts linked by the same institutional goals and the network of legal professionals (e.g. an English solicitor, Polish advocate, English Probate Court, etc.) helps to highlight intertextual relationships that a given text may have with the other texts. These relationships need to be identified since they may be indispensable in the analysis of the source texts and the subsequent successful construction of the translated professional text. In the case study described above, the goal of producing an acceptable affidavit by the Polish lawyer, as communicated in the first letter, can only be achieved if the accompanying documents (the Precedent and the Notes) are referred to and exploited adequately. Such texts are also an invaluable source of information about the professional space, i.e. wider context of the legal proceedings and their institutional goals.

This paper also draws the attention to preserving generic integrity in the translated document as one of the key components of generic competence at the textual level. The rejection of the affidavit described in the case study corroborates the well-known warning that "failure to employ [...] word combinations in accordance with the legally prescribed formulation will result in the invalidation of the whole text of which they form a part" (Kjaer 1990: 28). The second letter from the English solicitor provides negative feedback and signals that the translated document has not been accepted by the target professional group. The letter could be viewed as 'protest', i.e. response by the text receiver. According to the Skopos Theory a translated text can be regarded as successful if, in the target context, "it elicits no 'protest' to indicate that the message is not received in the manner intended and/or expected" (Nord 1997 cited in Hatim 2001: 75). Thus, a lack of reaction to the translated message indicates its 'success'. Unfortunately, this is not the case in the translation context described above.

The Polish lawyer's decision to deviate from the generic conventions of the documents may have been motivated by her desire to pursue her own professional goals. These goals may have involved preempting any attempt to challenge the will by the court and acting in the best interest of the beneficiaries by demanding that the legacies be paid immediately. As a result, there was a clash between the lawyer's professional goals and the institutional goal of the court.

Finally, this case illustrates problems linked to the translator's role and the loyalty (Nord 1991). The concept of loyalty seems particularly relevant given that the commissioning brief proved to be at variance with the needs 
and expectations of the target professional group (the English solicitor and the English court). Acquiring generic competence could help the translator to deal with such dilemmas.

\section{N O T E S}

${ }^{1}$ It should be noted that Pym (2003) distinguishes two more approaches: (1) nonexistence of translation competence (2) and two-language summation model. But they are not considered relevant in light of the present discussion.

2 The explanation of this concept is based on Bhatia 2004.

3 See UK websites providing useful information on different aspects of probate such as http://www.probate.uk.com/grant_of_probate.html or https://www.gov.uk/wills-probateinheritance/overview.

4 The concept of 'genre set' was extended by Bazerman (1994: 97) who proposes the concept of system of genres in an attempt to account for the full range of genres involved in a given professional practice.

5 The term 'advocate' is used here as a relatively neutral way to refer to "person who pleads cases in court" in international contexts (Lindner 2006: 11). Under the Polish legal system, advocates (Pol. adwokaci) have been admitted and belong to the legal profession. Their main professional duties involve providing legal advice to individuals and corporations, preparing legal opinion, drafting legal instruments and representing their clients before courts and other institutions (Jabłońska-Bonca 2004: 231).

${ }^{6}$ Explanation based on the definition from Oxford Dictionary of Law (Martin \& Law 2006).

\section{R E F E R E N C E S}

Bazerman, Ch. (1994). Systems of genres and the enhancement of social intentions. In: Freedman, Aviva/Medway, Peter (eds.): Genre and New Rhetoric. Taylor and Francis: London, pp. 79-101.

Berezowski, L. (2015). Jak czytać i rozumieć angielskie dokumenty notarialne, testament i pełnomocnictwa [Reading and understanding English deeds, last wills and powers of attorney] C.H. Beck: Warsaw.

Bhatia, V. (2004). Worlds of Written Discourse. Continuum: London.

Bhatia, V. (1993). Analysing Genre - Language Use in Professional Settings. Longman: London.

Biel, Ł. (2011). Professional realism in the legal translation classroom: translation competence and translator competence. Meta: Translators' Journal, vol. 56, no. 1, pp. 162-178.

Candlin, C. \& Bhatia, V. (1998). The Project Report on Strategies and Competencies in Legal Communication: A Study to Investigate the Communicative Needs of Legal Professionals. The Law Society of Hong Kong: Hong Kong. 
Devitt. A. (1991). Intertextuality in tax accounting: Generic, Referential and Functional. In: Bazerman, Ch. \& Paradis, J. (eds.) Textual Dynamics of the Professions: historical and contemporary studies of writing in professional communities. University of Wisconsin Press: Madison, pp. 336-357.

Giltrow, J. (2001). Meta-genre. In: Coe, Richard / Lingard, Lorelei / Teslenko, Tatiana (eds.): The rhetoric and ideology of genre: Strategies for stability and change. Hampton Press: Cresskill, NJ., pp. 187-206.

Hansen, G. (2008). The Speck in Your Brother's Eye - the Beam in Your Own: Quality Management in Translation and Revision. In: Gile, D., Hansen, G., Chesterman, A. and Gerzymisch-Arbogast, H. (eds.) Efforts and Models in Interpreting and Translation Research: a tribute to Daniel Gile, Benjamins: Amsterdam/Philadelphia, 149-162.

Hatim, B. (2001). Teaching and Researching Translation. Longman: Edinburgh.

Jabłońska-Bonca, J. (2004). Introduction to Law. Warsaw: LexisNexis.

Kjaer, A. (1990). Context-conditioned word combinations in legal language. IITF Journal 1/1-2, pp. 3-20.

Lave, J. and Wenger, E. (1991). Situated Learning: Legitimate Peripheral Participation. Cambridge University Press.

Lindner, A. (2006). International Legal English. A course for classroom or self-study use. Cambridge University Press: Cambridge.

Łachacz, O. \& R. Mańko (2013). Multilingualism at the Court of Justice of the European Union: Theoretical and Practical Aspects', Studies in Logic, Grammar and Rhetoric 34, pp. 75-92.

Martin, E. \& Law, J. (2006). Oxford Dictionary of Law. Oxford: Oxford University Press.

Nord, Ch. (1997). Translating as a Purposeful Activity: Functionalist Approaches Explained. St. Jerome: Manchester.

Pietrzak, P. (2015). Translation Competence. In: Bogucki, Ł., Goźdź-Roszkowski, S. and Stalmaszczyk P. (eds.) Ways to Translation. pp. 317-338. Łódź University Press: Łódź-Kraków.

Pym, A. (2003). Redefining Translation Competence in an Electronic Age: In Defence of a Minimalist Approach, In: Clas, A. (ed.) Meta: Translators' Journal (48), 481-497.

Swales, J. (1990). Genre Analysis: English in Academic and Research Settings. Cambridge: Cambridge University Press. 